\title{
Using intersectionality to explore social inequalities amongst Christian family migrants in China
}

Quan Gao and Peter Hopkins

School of Geography and Planning, Sun Yat-Sen University, China quan.gao@foxmail.com

School of Geography, Politics and Sociology, Newcastle University, UK

peter.hopkins@ncl.ac.uk

\begin{abstract}
In this paper, we explore how an intersectional frame offers new insights into the issue of social inequalities in relation to family migration. We bring research about family migration and intersectionality into conversation with one another by empirically examining the experiences of rural Christian family migrants in Shenzhen, China. We consider how neoliberal labour regimes and the Chinese state's project of building a secular and modernised state operates through an intersectional process of de-familiarisation that turns rural migrants into gendered, class-based, atomised labouring subjects. We argue that a more nuanced analysis of social inequalities in family migration could usefully focus on the intersectional processes within and among migrant families.
\end{abstract}

Keywords: intersectionality; religion; family migration; social inequality; China

\section{Introduction}

Zhigang is 35-year-old rural factory worker whom the first author met in an underground migrant church in Shenzhen, China. He and his wife lived separately in different factory 
dormitories and were seldom able to meet each other due to their shift work, even although they both lived in the same city. They had to leave their children at home in the countryside with relatives whilst they took up employment in the city. Zhigang considered himself as a $d a$ mangren (busy bee) and mocked himself: "I have to feed my family, serve God and sell my labour to the boss". Zhigang's situation exposes the intersectional identities and inequalities faced by the rural Christian (family) migrants in China. This is a group that emerges from the interplay of a series of contradictory social forces including the nationwide "Christian fever" and the massive rural-to-urban migration fuelled by China's reform and opening-up policy, and the state's strict control on religion and rural migrant labourers to produce productive and governable bodies (Gao 2020; Pun 2005). The phenomenon of rural Christian (family) migrants provides a social niche to reflect on the intersectional nature of social inequalities among rural migrants in China. This paper therefore addresses how the intersectional experiences of family migration in China can advance new understandings of social inequalities.

Over the past decade, there is increasing literature that incorporates the notion of intersectionality into debates about migration (Anthias 2012; Bürkner 2012; Calás, Ou \& Smircich 2013; Amelina \& Lutz 2018; Hopkins 2019; Bastia 2014). Broadly speaking, an intersectional approach to migration attends to the multiple social structures and inequalities that interact to shape the specific positions and identities of migrants (Anthias 2012). As Bürkner (2012: 192) notes, studies of migration have long been limited by taken-for-granted categories such as "ethnic community" and "marginalised subgroups", without considering the embeddedness of such categorisations and how these are co-produced by other social processes. In contrast, an intersectional approach emphasises an 'analysis of cross-cutting structural 
categories' and how it could 'allow for a better understanding of the emergence of individuals and collective social positions' (Bürkner 2012: 192). Among this research, one of the most valuable contributions is Anthias' $(2002 ; 2008 ; 2013)$ theorisation of intersectionality as "translocational positionality" in migration studies. This framework emphasises the intersections of different social positions of migrants, which may vary and be reconfigured in translocational contexts (Anthias 2002). A migrant may be in a contradictory position of advantage and disadvantage, exclusion and inclusion, simultaneously at different locations (Anthias 2012). Above all, this research indicates that intersectionality enables the complexity of migrants' locations and experiences to be exposed and better understood.

However, the scope and utility of intersectionality within studies of migration warrants further examination. First, ideas of intersectionality tend to be reduced to the exploration of the multifaceted nature of identities and how they reflect in migrants' lived experiences, while intersectionality as a process of becoming that may engender new subjectivities and agency is largely under-theorised (Collins 2019). In particular, the inter-constitution of different processes of categorisation may either produce new inequalities or reduce inequalities in other forms (McCall 2005). In other words, the intersectional structures always-already imply the formation of new political-ethical subjects (Collins 2019). In this paper, we argue that intersectionality also offers much value to scholars interested in migration in terms of how it enables examination of migrants' agency within a nexus of social relations and structures. Second, there is little research adopting the ideas of intersectionality in the context of family migration studies. The family as a unit for intersectional studies of inequalities has been acknowledged (Collins 1995; Pitre and Kushner 2015; Baylis and McLeod 2014). Collins (1995: 64) has noted that intersectional power and processes often operate through and 
manifest in 'family rhetoric and practices'. Not only is family itself an "object-target" for the reproduction of social inequalities but also, the formation of the family, can condition or constrain larger social processes of inequalities (Pitre and Kushner 2015; Hopkins 2006). This research necessitates the need to integrate appreciation of the family into intersectional approaches to migration studies and social inequalities.

In this article, we seek to establish the value of an intersectional approach to family migration studies by empirically examining the social inequalities and intersectional experiences of rural Christian family migrants in Shenzhen, China. On the one hand, we investigate how the Chinese state's regulation of rural family migrants operates through a process of defamiliarisation that turns rural migrants into class-based, gendered, atomised labouring subjects. Moreover, the state's strict regulation of religion further restricts Christian family migrants' everyday spaces and thereby facilitates social inequalities. This intersectional matrix serves the Chinese state's secular and neoliberal project of producing productive, governable yet alienated subjects. On the other hand, in response to Collins' (2019) argument of intersectional agency, we also illustrate that the intersections of religion, class and gender create new forms of agency for rural Christian migrants when it comes to family-making and belonging that reframes experiences of social inequalities. Christian family migrants' tactical utilisation of their intersectional positions enables them to rework the ways social inequalities are felt and performed, although the intersectional structure of domination is left largely unchallenged. Overall, we argue that a more nuanced analysis of social inequalities in family migration should focus on the intersectional processes within and among migrant families, from which multiple forms of social oppressions operate but also from which migrants' agency may emerge. 
Applying intersectionality to migration should focus on both processes as well as the structural arrangements of power.

\section{Family migration and social inequality: an intersectional approach}

Inequalities in relation to migration is one of the key global challenges facing societies today (Martin 2013). Migration itself is the outcome of social and economic inequalities, such as the increasing disparities in wealth and opportunity, uneven regional development, and various forms of social oppressions. On the one hand, migration may potentially disrupt unequal social structures, as people move to escape existing social constraints and oppressions (Bastia 2014). For example, some feminist geographers have emphasised that migration can reconstitute the spatial condition of gendered power relations and in particular patriarchy; women migrants are capable of challenging or subverting patriarchal norms and their material base while they embrace more equal societies in new socio-economic environments (Pratt and Yeoh 2003; Silvey 2004). On the other hand, however, migration may also reproduce social inequalities as they are subject to new regimes of class, religion, ethnicity, citizenship, and gender in host societies (Long 2015). Migrants are increasingly considered as the "object-target" for neoliberal governance, through which host societies make efforts to maximise migrants' economic utility while diminishing their consumption of social welfare (Ong 2007; Gao 2020).

This is particularly the case for family migrants who are often viewed as an unwanted group that are more difficult to integrate into the neoliberal labour market and the mainstream culture of receiving societies compared to individual migrants (Bürkner 2012). For example, as Kofman (2004: 248) argues, family migration is treated "in policy terms as a secondary type 
of migration, viewed initially as an unintended consequence of the stoppage of mass labour migration [...], and consisting of female dependents following the male breadwinner as the primary migrant”. The immigration legislation of European countries in 1970s was often based on the unwarranted gendered assumption that women in family migration were less likely to seek employment. Although this stereotype has been substantially challenged by the fact that women have increasingly participated in global capitalism for many years, family migration is still considered to be the burden of neoliberal production and welfare systems (Gao 2020). Pun's $(1999 ; 2005)$ study of Chinese "dagongmei” suggests that young single rather than married women are congruent with the neoliberal factory regime that heavily depends on the docile, productive, and flexible, young labour. Moreover, single young workers are coincided with the labour camps designated to accommodate large number of migrant labourers without burdening the urban public housing system in China (Pun 2005).

The Chinese state has imposed a set of institutional barriers to migrant workers establishment of families in the city, one of which is the hukou system that denies their urban citizenship and in particular their access to healthcare and education in the city (Zhang 2001; Qian and He 2012). In the cultural sphere, family migrants are often associated with entrenched tradition or religious conservatism and therefore are socially and culturally incompatible with the liberaldemocratic values of the West. For example, the Islamic family values that emphasise piety and gendered role are publicly conceived as an impediment to social integration and gender equality in some Western immigrant countries (Diehl, Koenig \& Ruckdeschel 2009); this works to reinforce their otherness and to stereotype them such that 'all Muslim men as potential terrorists, Muslim women as helpless victims of oppression, and Islam as inherently tyrannical, violent and patriarchal' (Gökarıksel 2017: 469). This gendered cultural representation indeed 
justifies the sentiments of Islamophobia, which sets the emotional basis for other forms of inequality and oppression on Muslim migrants (Hopkins 2019). In short, existing literature on migration has highlighted that social inequalities are better understood through migrants' translocal and multiple subjectivities (Silvey 2013). The social construction of multiple identities (e.g. rurality, ethnicity and gender) structure the way that social inequalities are felt and performed in migrants' everyday life (Silvey 2013).

However, notwithstanding the acknowledgement of multiple identities and inequalities in (family) migration studies, this line of scholarship tends to focus on the singular social hierarchy between migrant and non-migrant groups, constructing family migrants as socially homogeneous groups who experience similar inequalities (Collins, Simon-Kumar \& Friesen 2020). What is largely unexplored is the relational processes and multiple experiences of social inequalities, especially how different forms of social oppression form and constitute one another to produce a matrix of social structures that condition the experiences and functioning of family migration. We address this concern by exploring how using intersectionality has the potential to enhance the field; in this case, we argue it can enable new understandings of social inequalities in the context of family migration.

Using intersectionality involves examining the interlocking of different categories (Cho, Crenshaw and McCall 2013). As Bilge and Collins (2020: 2) argue, intersectionality is a way of understanding the complexity of social inequality: "when it comes to social inequality, people's lives and the organization of power in a given society are better understood as being shaped not by a single axis of social division, be it race or gender or class, but by many axes that work together and influence each other". In essence, Collins (1995: 64) has argued that 
family itself is a site of interlocking power, as ethnicity, gender and migration 'intersect in family rhetoric and practices'. Thus, a more comprehensive analyse of family would uncover how the systems of inequalities operate via intersectional processes (Pitre and Kushner 2015). In this sense, deploying intersectionality in studies of family migration would examine not only the intersectional experiences and inequalities among family members themselves but also how different forms of social forces operate in and through the family.

The migrant family is a rhetoric or "object-target" for the operation of social inequalities and therefore research needs to uncover the intersectional power that influences 'family functioning and well-being' (Pitre and Kushner 2015: 285). Collins' (1995: 62) early work has elucidated family as a basic functioning unit through which 'a gendered system of social organization, racial ideas and practices, and constructions of U.S. national identity' are embodied and materialised. Yet, some scholars also point out that family functioning and family-making also provide a crucial approach to resist discriminations and hegemonic social norms and thereby to condition the mechanism by which social inequalities actualise as part of the everyday life of family members (Baylis and McLeod 2014). For example, the family-making of lesbian women through assisted reproduction is an important way to reclaim their desires for parenthood and to resist heterosexual hegemony (Rozental and Malmquist 2015). In this paper, we address these two aspects by exploring the intersectional processes within and among family migration.

Methodologically, an intersectional approach to family migration would focus on multiple categorisations as well as the relational, contextualised and mutually constitutive nature of social inequalities (Hancock 2016; Hopkins 2019). For Crenshaw (1993), intersectionality 
recognises not only the connectedness of different structures that affect individuals differently (structural intersectionality) but also the cultural representations that maintain and reproduce categorisations (representational intersectionality). Crenshaw's (1993) concept of structural intersectionality indicates that "there is not only social ascription and identity building at work but also a material basis for inequality" (Bürkner 2012: 183; Verloo 2006). Here, McCall's (2005) conceptualisation of intersectionality as anti-categorical, intra-categorical, and intercategorical complexities provides a crucial intersectional methodology for examining categorisation and social inequalities among family migration. First, anti-categorical complexity is based on the poststructural critique that deconstructs the analytical categories and the inequalities they sustain. Thus, to deconstruct the normative categories is to deconstruct social inequality per se, since "symbolic violence and material inequalities are rooted in relationships that are define by race, class, sexuality, and gender" (McCall 2005: 1777). Considering this, scholars should focus on the social process of categorisations that stabilise inequality rather than simply mapping out multiple categories of family migration. However, some scholars contend that anti-categorical approach should be utilised much more than poststructuralist critique that emphasizes social and cultural formation of inequalities, because the researcher must acknowledge that each category is ontologically distinctive, with techniques of inferiorization and marginalization (Yuval-Davis 2015; Anthias \& Yuval-Davis 2005). In this paper, we highlight how class-based exploitation structures other categorisations of gender and migration. Second, intracategorical complexity interrogates 'particular social groups at neglected points of intersection' 'to reveal the complexity of lived experience within such groups' (McCall 2005: 1773). To engage this approach, the researcher must be attentive to a social group that is excluded from the dominant categories represented in mainstream society and situate them within a specific social setting in which they are affected by, or negotiate with, marginalised experiences. In the paper, we explore the experiences of rural 
Christian family migrants, a group who are largely ignored by Chinese society. Third, the intercategorical complexity attends to the 'relationships of inequality among social groups and changing configurations of inequality along multiple and conflicting dimensions' (McCall 2005: 1773). In this sense, a single social group's categories are not fixed but subject to change. McCall (2005: 1791) argues that "some forms of inequality seem to arise from the same conditions that might reduce other forms". Therefore, the inter-categorical approach pays attention to the changing context in which social powers are organised. To engage the intercategorical complexity, this paper focuses on how religion may mediate and reconfigure classbased and gendered arrangements of power among family migrants. Existing research on geography of religion has noted that religion plays a crucial role in addressing social inequalities among migrant community (Ley 2008; Gao and Qian 2018; Kong and Woods 2019). In particular, faith-based organisations and religious institutions - such as Christian churches - increasingly provide social welfare services no longer offered by the state by providing migrants with bonding social capital, caring and solidarity (Ley 2008; Cloke 2013). Religion therefore offers migrants not only social and material supports but also therapeutic and emotional empowerment enabling them to reframe the experiences of various social oppressions (Cloke and Beaumont 2013; Gao et al. 2019). As Gao et al. (2019) suggest, although religious ethics cannot substantially challenge the ontological conditions of social inequality, it constitutes an "structure of feeling" that conditions the ways various forms of power operate and are actualised.

Nevertheless, the agency of religion in migrants' life needs to be understood within the intersectional nexus and structure that they are situated. In this sense, intersectional thinking 
demands us to focus on not only the multiple forms of social inequalities but also the possibility of agency that may emerge within this structure. As Collins (2019: 26) recently puts it:

The idea of intersectionality works in multiple registers of recognizing the significance of social structural arrangements of power, how individual and group experiences reflect those structural intersections, and how political marginality might engender new subjectivities and agency.

Collins (2019) recognises the tension between intersectionality as the reality of oppression and intersectionality as a process of becoming that might open spaces of possibility and freedoms that resist and challenge social inequalities. For Collins and Bilge (2020), intersectionality is not simply about identity politics but also provides a relational and situated context to understand the ways individuals inhabit and navigate their multiple subjectivities. Intersectionality as a social context 'matters in how people use identity to create space for personal freedom' (Collins and Bilge 2020: 153). Thus, an intersectional approach to agency would 'insist that there is no ontological priority of agency to context, and would turn its focus instead to specific contexts and articulated social formations from which different forms of agency and subject positions arise' (Bilge 2010: 23). In other words, migrants' (religious) agency is better understood to be a relation of emergence, which forms within a nexus of social relations and structures. In response to Collins (2019) and Bilge's (2010) insights, we argue that a more nuanced analysis of social inequalities in family migration should focus on the intersectional processes from which multiple forms of social oppressions operate but also from which migrants' agency may emerge.

\section{The study}


This study is part of a larger project that investigated the everyday life and regulatory politics of rural migration in Shenzhen, China. It used an intersectional analytical frame to explore rural migrant workers' religious, gender and class subjectivities under the state's neoliberal transition in the post-reformed era. Our data are drawn from the fieldwork during September 2017 to March 2018 conducted with 52 rural Christian migrant workers ( 32 men and 20 women) and 8 church leaders in Shenzhen's 9 Protestant churches. 12 of the 52 migrant workers are married couples with age varying from 23 to 42; these 6 Christian migrant families are the primary focus of this paper. Among these 6 married couples, 3 married in churches in Shenzhen, while the others are rural Christian couples who married before migrating to the city.

Methods utilised in this study included participant observation and in-depth interviews. The methodological challenge of this paper is that "it is difficult to find specific proposals, methods or tools that help the process of researching intersectionality" (Rodó-de-Zárate and Baylina 2018). McCall (2005) considers case study and story narrative as the most effective way to research intersectionality as multiple experiences in subjects' everyday lives. Hopkins (2018) contends that methods that are open to diverse forms of participation are important for capturing the complexity of intersectional experiences, as they provide an open and explanatory approach for participants to narrate what social divisions matter to themselves. Following Hopkins (2018: 588), we therefore use opened interview to 'provide space for our participants to talk through the social divisions most significant to them'. We followed family migrants' everyday life and the practices of family-making in and beyond the churches, factories and living spaces. We also participated in sermons, fellowships and other religious activities organised by the local churches. 
Each interview lasted between 40 minutes and 3 hours. We used snowballing to recruit informants, with the assistance of a Christian migrant family who had established a migrant church in Shenzhen. All names of informants in this paper are pseudonyms. As both the researchers are non-Christian, we therefore engaged with methodological agnosticism during the research; that is, we suspended our judgements on the religious values but exchanged ideas with the participants so to encourage them reflect on their lived experiences (Cox 2010).

\section{Rural Christian family migration under intersectional matrix of inequalities}

China's political and economic reform and especially its integration into the global economy since the early 1980s has released large-scale surplus farm labour who migrated into the city in search of a better life. The National Bureau of Statistics of China has reported that there were approximately 281.71 million urban residents who were rural-to-urban migrant workers in $2017^{1}$. These rural migrant workers constitute not only the key actors in China's rise as "the workshop of the world" but also the most marginalised group in contemporary China (Pun \& Smith 2007). However, most rural migrants are sole migrants who work individually in the city or are split household coupled migrants who leave their children behind in the countryside (Fan 2005; Fan \& Sun 2011). Inflicted by both the state's regulation of rural migrants and the neoliberal migrant labour regime (Gao 2020; Gao \& Qian 2020), rural migrants face a variety of institutional barriers that limit them from forming and maintaining a family in the city. Alongside the drastic economic growth in China is an astounding religious revival and the unlikely "Christianity fever" which has taken place over the last three decades. There were at least 58 million Protestants in China in 2010, having increased almost tenfold over a period of

\footnotetext{
${ }^{1}$ http://www.mohrss.gov.cn/SYrlzyhshbzb/dongtaixinwen/buneiyaowen/201705/t20170502_270286.html
} 
30 years (Pew Research Centre 2010). The intersections of rural-to-urban migration, class and the nationwide Christian revival in China has given rise to a new a distinctive social group Christian migrant workers. In this section, by focusing on the lived experiences of rural Christian migrant families ${ }^{2}$, we reflect on the intersectional matrix of social inequalities that they experience. We suggest that the coalition of neoliberal labour regimes and the Chinese state work to manage and control Christian family migrants through an intersectional process of de-familiarisation that turns them into gendered, class-based, atomised labouring subjects.

Since early 1980s, China has switched its role from Maoist state of central planning to a marketoriented developmentalist state. Despite the adaption of market-oriented logics, migrant control has been a crucial agenda for the state to achieve capital accumulation and maintain economic competitiveness under the "global division of labour" (Pun 2006). In other words, how to manage the large reservoir of migrant labourers - to maximise their economic utility while diminishing their labour costs and consumption of welfare in the city - has been a crucial task for China's neoliberal reform (Gao 2020; Ong 2007). Migrant families become important "object-targets" for the state's strategies of migration control. In contemporary China, the hukou system ${ }^{3}$ is still one of the most prominent mechanisms determining the distribution of social resources, and more broadly access to full urban citizenship, providing the basis for the most prominent form of institutional exclusion practised against rural migrants in urban space (Chan and Buckingham 2009). Under the hukou system, rural residents and migrants are treated

\footnotetext{
${ }^{2}$ Family migrant here refers to a social unit of migration that consists of at least a married couple.

${ }^{3}$ Hukou system is a household registration system required by the law of population management in China. It officially categorised individuals as a "urban" or "rural" citizen. Migrant workers with rural hukou therefore have far less eligibility to welfare and government service in the city, living in a situation similar to that of illegal immigrants.
} 
as inferior citizens deprived of rights to settle in cities as permanent residents and to most statesponsored benefits and welfare enjoyed by urban residents, ranging from medical services to children's education (Chan and Buckingham 2009). In this sense, we suggest that hukou system serves as the de-familiarization of rural migrants that turns them into atomised, selfresponsible, labouring subjects.

Take for example, Yu's family, a rural migrant household with three people: Yu (a 32-yearold assembly line worker at Foxconn company), Yu's wife (a 29-year-old factory worker), and their 6-year-old son who was attending a private pre-school in Shenzhen. Different from most rural migrant couples who leave their children behind the countryside, Yu made efforts to keep his son around to foster a healthy environment for their child to grow up in and to gain a better education. However, without a Shenzhen hukou, Yu's son was not eligible to attend continually Shenzhen's primary school after he finished his preschool education. It means Yu had to send his child back to their hometown for primary education. As Yu said:

"We don't mind the hardship of making a living in Shenzhen, it's all for our son. But it quite saddens us that we are not capable of sending our child to Shenzhen's primary school because of the hukou... If you are able to buy a property in Shenzhen, you can gain a Shenzhen hukou quickly and let your child attend the school nearby. But it is unimaginable for us to buy a property here."

As is evident in Yu's family, by establishing a social order that denies rights to rural migrant workers, the state can treat rural migrants as simply temporary labour. Embedded in this urban- 
rural division system is a form of neoliberal urbanism - the state can enable a large supply of free-floating rural labour to feed industrialization and urban development and simultaneously minimise the burdens placed upon them. However, we argue that the hukou system is not simply a place-based social inequality but rather intersects with social inequalities such as class exploitation and gender domination, which interactively forms the migrant labour regime that classifies and separates rural migrants into gendered, class-based, atomised, labouring subjects in tandem with neoliberal urbanism.

In another example, Fang (26-year-old factory workers at Foxconn) and Li (25-year-old hotel waitress) are a married couple who both work in Shenzhen. However, maintaining a family in Shenzhen is a challenging task for them. Despite being in the same city, they are forced to live separately due to their work. To meet the intensive workload and the just-in-time production model in Foxconn, one of the largest manufacturing factories in China, Fang must live in the factory dormitory and has limited times to be with his wife. As a hotel waitress, Li also lives in the collective dormitory provided by the hotel in order to minimise her daily expenditure. Fang and Li were planning to have a child in the future, but they were reluctant because of the difficulties they faced. As Li told us emotionally: "We don't even have a home here, so we don't want our child bear the hardships of their parents."

Fang and Li are subject to different regimes of labour that are highly segregated by gender. Service sectors and manufacturing factories tend to recruit young, single, rural women migrants as they are constructed as being submissive and 'as having good attention to detail, able to handle delicate work' (Fan 2007: 5). On the other hand, male migrant workers are often associated with physical work such as construction. Under such a migrant labour regime, 
migrant workers were intentionally largely atomised as isolated subjects and were deprived of emotional support from family and friends. For example, Fang complained that the intensive workloads and work schedules constantly shuffled him and his wife from day to night shifts, with little interaction with each other. In the Foxconn company, married couples are separated in different dormitories strictly segregated between men and women. Even roommates in the same dormitory could hardly ever meet each other if they worked different shifts. As Fang noted:

Fang: After work, it is usually during 8-9 p.m., and then I take a quick shower and fall into sleep. Sometimes we don't even have Sunday if there are too much workload assigned to you. So we (Fang and Li) usually meet once a week.

Researcher: Do you feel isolated?

Fang: Yeah, not only because my wife and I have to live separately but also because you can't even have stable friendship here in Foxconn. Most young people aren't willing to stay long in Foxconn. Normally, they had worked for 1 year or so and then switched to another job. Your workmates and dormmates are always changing. There were 8 people in our dormitory. Because I worked on day shifts, I only saw them sleeping when I came back at night. So, we scarcely had any communication ...

Fang and Li's forced separation illustrates that the migrant labour regime co-constituted by state power and global capitalism is not only class-based but also gendered. Young single migrants, rather than family migrants, are more congruent with Shenzhen's neoliberal urbanism that heavily depends on the productive, and flexible, young labourers. This can be 
illustrated by the fact that Shenzhen has the youngest mean age (32.5) and the highest unmarried (68\%) rate of its population among China's cities ${ }^{4}$. As such, family migrants are facing a variety of institutional barriers and social inequalities that restrict them from establishing and maintaining a family in Shenzhen. For instance, the intensive expansion of factory dormitories initiated by global capitalism in Shenzhen was encouraged by the government as an alternative means of accommodating large numbers of low-skilled and lowpaid migrant workers (Pun and Smith 2007). The factory dormitories can be viewed as the migrant labour camps that are detached from the protections and welfare system of Shenzhen, such that the burden of housing rural migrants is successfully channelled to the global capitalists.

Apart from the neoliberal migrant labour regime, rural Christian family migrants are also subject to state's strict regulation of religion that further marginalises them. In China, most Christian evangelical movements thrive in rural areas away from the surveillance of the state (Huang 2014). Among the 58 million Protestants in China, two thirds of them are rural Christians. However, this situation is changing as tens of millions of rural Christians have migrated into cities in search of a better life. It is noteworthy that many rural Christian families or couples moved to the city not only in search of a livelihood but also because they were motivated by religion and by the establishment of new churches in the city.

Hui was a preacher in one rural church in Henan Province. In 2012, Hui, together with his Christian wife and two daughters, were assigned by their local church to establish an

\footnotetext{
${ }^{4}$ https://baijiahao.baidu.com/s?id=1666026231912391464\&wfr=spider\&for=pc
} 
underground church in Shenzhen. It is not uncommon that rural Christians become the major actors of the underground church movements in China's cities. As Koesel (2013) suggests, much like the spread of communism in China during 1910s-1930s, the development of underground Protestantism in contemporary China also adopted similar organisational tactics (e.g. underground organisations and the communist strategy of "encircling the city with the countryside") in order to survive in a hostile political environment. As Hui recalled, his family was among the 15 Christian families that were called out to "occupy the city". Before departure, these 15 Christian families received one-month preaching training course delivered by the China Gospel Fellowship (CGF) (中华福音团契), China’s largest house church. As Hui said: "All the families responded with great enthusiasm and we couldn't wait to spread the gospel to the city". However, Christian families in urban China encounter state regulation and surveillance of religious groups but also the discrimination from dominantly atheist citizens. Hui told us their difficulties of operating a house church and doing religious activities in Shenzhen:

You know, house church is illegal so I have to constantly switch the places of congregation to avoid that the police would find us. We need to ensure that each fellow who participates in our church is reliable... In terms of the evangelisation, many people still have many misunderstandings about Christians. Once, when I intended to bring gospel to someone, he was mad at me. He said what I believed was foreigners' and tried to call the police. So I gave up.

The view of the state is that religious organisations are believed to threaten the governance of a totalising party-state and are at odd with the secularist ideologies of reasons, progress and 
efficiency that support China neoliberal reforms (Yang 2011). In this sense, the Chinese state's strict regulation of religion is incorporated into and mutually constituted within "China's state developmentalism and the autocratic rule that produces docile and governable subjects" (Gao 2020: 2).

Overall, the neoliberal labour regime operates through the intersections of migration, gender, and class, which de-familiarizes and alienates rural migrants into atomised labouring subjects. Moreover, the state's strict regulation of religion further facilitates the marginalisation of rural Christian family migrants who become "object-targets" of the state's neoliberal and secular projects of producing productive, docile and governable subjects. In this sense, rural Christian family migrants are subject to what Collins (2000) calls a "matrix of domination" that grounds the basis for an overarching structure of inequality.

\section{The intersectional agency of rural Christian family migrants}

As we have analysed above, state's regulation of migrants and religion largely turn rural Christian migrants into alienated, atomised, and governable labouring subjects. However, in what follows, we demonstrate that the intersections of religion, gender, class, and migration also open a space of community and family-making that enables rural family migrants to negotiate with these intersectional social inequalities. As Collins (2019) argues, intersectionality can enable greater appreciation of the agency that may arise from interaction of different forms of identification and processes of marginalisation. Although rural Christian family migrants are experiencing multiple marginalisations, they are nevertheless capable of 
reframing their marginal subjectivities by drawing on their intersectional relationalities and identities.

In Shenzhen, Christianity has noticeable influences upon migrant working-class communities. In some churches in and around manufacturing zones, migrant workers constitute more than 80 per cent of the church attenders (see also Gao \& Qian 2020). This is not only because a significant proportion of rural migrants have been Christians before migrating to the city but also due to the increasing involvement of Protestant churches in providing both social support and care for migrant workers. These religious organisations serve as the "service hubs" (Ley 2008) that provide social networks and employment opportunities, and help migrants integrate through mutual assistance and social interaction with local Christians. However, these Christian working-class communities also enable rural migrants to reclaim practices of familymaking by establishing a church-based family life. In contrast to the migrant labour regime that alienates rural migrants, the church serves as an emotional space in which migrant workers can form intimate relationships with one another. Many churches not only encourage faith-based marriage between Christian rural migrants but also serve as "marriage agents" for them. These churches normally have fellowships called dan shen tuan qi (单身团契) for single Christian workers and regularly organise outdoor activities to help Christian workers familiarise themselves with each other. Therefore, it is very common that young Christian workers to find a spouse and establish a family with the assistance of the church.

Zhiqiang (a 35-year-old factory worker), his wife Lifang (a 32-year-old factory worker), and their 2-year-old child Lili, were a typical Christian migrant family that we visited. Before meeting Lifang, Zhiqiang was a single rural migrant who had been worked at Foxconn for 6 
years and was promoted to an assembly line leader in 2016. However, as he noted, a single young man in his 30 s is often viewed negatively within Chinese familial traditions with most of the young men in his village having already married. In 2015, Zhiqiang was asked to return to the village to attend a blind date (xiangqin 相亲) that his parents arranged for him. However, Zhiqiang refused to meet the woman his parents had chosen, not only because he did not want to find a spouse with no Christian conviction, but also because they had to live separately if they had married. Normally, married migrant women would return to their village for maternity while the husbands stay in the city as a 'breadwinner', and some married rural women would return to the city in search of livelihood again with their children left to the grandparents in the village. This is a common mode of living for many Chinese rural migrant families yet not an ideal one for Zhiqiang, as he wants to settle down in Shenzhen. In this sense, the Christian community provide him with a specific form of agency to seek a desired type of marriage and family. As Zhiqiang recalls, when he first indicated interest in Lifang, other church members helped him to elicit a response. For many Christian migrant couples like Zhiqiang and Lifang, once relationships are made public, the church fellowship would guidance on marriage and family relationships.

The Christian communities and the Christian family values they uphold play a crucial role in shaping the gendered family relationships of migrant families. Apart from regularly organised sermons that teach Christian couples to cultivate a strong marriage in line with Christian ethics, the churches also emphasise the sharing of testimonies and emotional experiences of Christian couples, such that they can build a 'godly marriage' based on their biblical values and common faith. Chief among these Christian family values is the teaching of men's headship that 
emphasises the gender role of a family. For example, Fang and his wife, Li, explain how the enactment of this teaching can help them maintain a harmonious marriage:

Interviewer: How do you understand the principle of men's headship and its influences on your marriage?

Li: I can find out this to you, the Bible says: "Wives, submit to your husbands as to the Lord" and "For the husband is the head of the wife as Christ is the head of the church, his body, of which he is the Savior" (Ephesians 5:22-23). This is not to say that wives should submit to their husband unconditionally; rather, it means that the wife should respect and understand her husband. You should encourage your husband to be the spiritual leader of the family and to take more responsibilities of the family.

Fang: Yes, Men's headship also means men should take more responsibilities than women... So, the wife should assist her husband and help him better perform his role. The Bible also says: "Husbands should love their wives as their own bodies because they are one flesh." So husbands should love their wives... If you have this common faith, once conflicts and difficulties occur, you can figure them out together.

In contrast to the neoliberal labour regime that alienates the emotional connections between family members, Christian understandings of gender highlighted in the quotation above enable migrant workers to maintain an intimate family relationship and thereby enhance the emotional process of family-making. 
Moreover, the Christian churches also offer a communal life that permeates into many aspects of the family life of rural migrants, especially leisure activities and childcare. For example, some churches also provide free childcare services for migrant workers' children. Although most migrant couples would send their children to kindergarten during workdays, some migrant parents are forced to work overtime at weekends due to the exploitative factory regime. Thus, how to settle migrants' children while parents are both absent from home is a challenging problem for many rural migrant families. In response to this problem, one church located next to the Foxconn Company established a childcare centre that helps migrant workers look after their children during weekends or helps them pick up children from kindergartens in the afternoon. For example, once Zhiqiang and Lifang had to work an extra shift at the factory, their children can be temporarily settled and taken care of at the childcare centre or other workers' home until they finish work. As Zhiqiang and Lifang express, although they live in a cheap rental room, they can emotionally settle down in Shenzhen due to this religious community. In this sense, these Christian-based communities not only enhance migrant workers' family-making practices but also cultivate a sense of working-class solidarity within these marginalised groups.

It is noteworthy that many house churches consciously position themselves as working-class religious communities serving rural migrant workers. These communities have become increasingly involved in offering both social support and spiritual care for rural migrants and their families. As a result, these house churches have undergone rapid expansion due to their social involvement with the working class. According to the leader of one house church, there are at least 6 house churches around the Longhua branch of Foxconn company, most of which are dominated by migrant workers. This has particularly been the case since the Foxconn 
suicide event. In 2010, 18 young workers attempted suicide by successively jumping from the production facilities at Foxconn; 14 died. The Foxconn suicide event can be understood in the context of the long-term depression and alienation experienced by the migrant workers due to the neoliberal migrant labour regime. Since then, many Protestant house churches started to target migrant workers for social services, among which Foxconn House Church A and B are two typical working-class religious communities. Due to the militarised management and the lack of social and emotional supports for migrant workers, depression and other psychological problems have become a significant trouble for the Foxconn company. Instead, these churches offer them a form of communal life that enables them to alleviate this sense of alienation. In this situation, the Foxconn company even formed partnership with Foxconn House Church A who they worked collaboratively with to help psychologically vulnerable workers. As the church leader Chan told us:

Actually we have cooperative relationship with Foxconn. They understand the core values of Christianity and know it may help workers. You know, many Taiwanese senior managers are actually Christians ${ }^{5}$. Of course, Foxconn has their own psychotherapists to help workers. However, if it doesn't work, they would ask the worker if he wants to go to the church as an alternative.

Interestingly, these churches' social engagements with working-class communities have established a subtle triangle relationship between the Church, Foxconn company, and

\footnotetext{
${ }^{5}$ Foxconn is a Taiwanese-own manufacturing company so many positions of senior managers are taken by Taiwanese.
} 
municipal government. Religious communities' interventions for migrant workers and their families filled a gap in social support and welfare not provided by the state or the capitalists. Although the Chinese state often exerts strict control over Christian organisations, their social significances are not totally denied by the state. As Gao and Qian (2019:69) argues: "Christian values, and particularly the concept of love, are compatible with the [Chinese] state's efforts to construct a 'harmonious society' by propagating state-endorsed moral standards and filling up the gap of social welfare and services". As the leader of Foxconn House Church B remarked, although their house church was found by the police who had come to investigate, the government has neither acknowledged their legal existence nor taken coercive actions to shut down the church. The church therefore has received the government's acquiescence. In this sense, the structure of the church does not fundamentally challenge - but rather is integral to the state and the neoliberal project of producing docile and productive labouring subjects by enhancing rural migrants' emotional resilience to cope with social inequalities.

In summary, rural Christian family migrants and their churches they affiliate with are able to reclaim both religious spaces and the agency of family-making that are largely constrained by the coalition of the state and the neoliberal labour regime, by tactically utilising their intersectional relations, identities and cultural resources. Although Christian family migrants are subject to multiple social inequalities that operate through categorisation of migration, class, gender and religion, the mutual constitution of these identities may also in turn open the potential for agency that works to reframe their marginalised experiences. On the one hand, the Christian identity may situate family migrants in a more marginalised position, alongside the class-based and gendered inequalities they already experience. On the other hand, however, as McCall (2005: 1791) argues, the intersectional inequalities do not have an additive effect 
because some forms of inequality might condition other forms. From an inter-categorical approach of intersectionality (McCall 2005), we need to pay attention to how different processes of identification mutually shape and interact with one another. In this case, the interactions of religion with class, gender and migration (e.g. the Christian ways of familymaking, gender relationships, the making of working-class religious communities, and the church's strategies of social engagement) enable family migrants to either reframe the experiences of class-based inequality or tactically rework the ways social inequalities operate. Yet, we also note the limitations of Christian family migrants' agency that it cannot substantially alter the intersectional "matrix of domination" (Collins 2000). As McCall (2005) suggests, some forms of inequality are more salient than others, rendering visible the central role in shaping the experiences of oppression. In this case, the class-based structure facilitated by neoliberal labour regime and hukou system largely conditions the extent to which rural migrant can exercise their religious agency.

\section{Conclusions}

In this paper, we have provided a case study of utilising intersectionality in family migration studies and sought to advance an intersectional and relational understanding of both social inequality and migrants' agency. First, this paper advances an intersectional approach to family migrant studies. Family - as both rhetoric and practices - is important to understanding the intersectional processes of social inequalities among migrants (Collins 1995). In this case, the migrant labour regime operates through the projects of de-familiarisation that break down family migrants into class-based, gendered, individual labouring subjects. The neoliberal urbanism of Shenzhen as well as party-state's larger project of building a secular and modernised nation create an intersectional matrix of inequality that thwarts family migrants' 
agenda of family-making and integration into the city. In doing so, we highlight not only the intersectional structure of social inequality but also the new intersectional subjectivities and agency that emerges from and within this structure.

Second, we contribute to geographies of religion by providing an intersectional account of (religious) agency. Family migrants tactically utilise their intersectional positions and cultural resources to negotiate with the social inequalities. The intersections of religion, class and gender open ethical and political space that reworks how social inequalities are felt and performed. In this sense, what Collins (2002) calls the intersectional "matrix of domination" is not a processive characteristics imposed on family migrants; it is also a process of becoming (Collins 2019) in which family migrants can constitute their own intersectional subjectivities and relations in response to the social inequalities they are experienced. Methodologically, through the situated examination of the McCall's (2005) inter-categorical approach, we argue that migrants' religious agency is not singular but rather emerges through its mutual constitution with other social divisions. It is shaped by the way individuals navigate their "translocational positionality" within the intersectional matrix of power (Anthias 2002). In summary, a more nuanced utilisation of intersectionality within geography of religion and migration could usefully delve into complex intersectional processes rather than simply identifying the structural arrangement of power.

\section{Acknowledgments}

Many thanks to Newcastle University's Research Excellence Academy for funding this research and to all participants who shared their experiences.

\section{References}


Anthias, F. (2002). Where do I belong?: narrating collective identity and translocational positionality, Ethnicities, 2(4), 491-514. http://doi.org/10.1177/14687968020020040301

Anthias, F. (2008). Thinking through the lens of translocational positionality: an intersectionality frame for understanding identity and belonging. Translocations, Migration and Change, 4(1), 5-20.

Anthias, F. (2012). Transnational mobilities, migration research and intersectionality. Nordic Journal of Migration Research, 2(2), 102-110. http://doi.org/10.2478/v10202-011-0032-y

Anthias, F. (2013). Intersectional what? Social divisions, intersectionality and levels of analysis. Ethnicities, 13(1), 3-19. http://doi.org/10.1177/1468796812463547

Anthias, F., \& Yuval-Davis, N. (2005). Racialized boundaries: Race, nation, gender, colour and class and the anti-racist struggle. London: Routledge.

Bastia, T. (2014). Intersectionality, migration and development. Progress in Development Studies, 14(3), 237-248. http://doi.org/10.1177/1464993414521330

Baylis, F., and McLeod C.(eds). (2014). Family-making: contemporary ethical challenges. Oxford: OUP Oxford.

Bilge, S. (2010). Beyond subordination vs. resistance: An intersectional approach to the agency of veiled Muslim women. Journal of Intercultural Studies, 31(1), 9-28. http://doi.org/10.1080/07256860903477662

Bilge, S., \& Collins, P. H. (2020). Intersectionality. Cambridge, UK: Polity.

Bürkner, H.J. (2012). Intersectionality: How gender studies might inspire the analysis of social inequality among migrants. Population, Space and Place, 18(2), 181-195.

http://doi.org/10.1002/psp.664

Calás, M. B., Ou, H., \& Smircich, L. (2013). "Woman" on the move: Mobile subjectivities after intersectionality. Equality, Diversity and Inclusion: An International Journal, 32(8), 708-731. http://doi.org/10.1108/EDI-05-2012-0037 
Chan, K. W., \& Buckingham, W. (2008). Is China abolishing the hukou system?. The China Quarterly, 195, 582-606. https://doi.org/10.1017/S0305741008000787

Cho, S., Crenshaw, K. W., \& McCall, L. (2013). Toward a field of intersectionality studies: Theory, applications, and praxis. Signs: Journal of Women in Culture and Society, 38(4), 785-810. https://doi.org/10.1086/669608

Crenshaw, K. (1993). Beyond racism and misogyny: Black feminism and 2 Live Crew. In Meyers, D.T.(ed). Feminist social thought: A reader (pp. 245-263).

Collins, P. H. (1998). It's all in the family: Intersections of gender, race, and nation. Hypatia, 13(3), 62-82. https://www.jstor.org/stable/3810699

Collins, P.H. (2002). Black feminist thought: Knowledge, Consciousness, and the Politics of Empowerment. London: Routledge.

Collins, P.H. (2019). Intersectionality as critical social theory. Durham, US: Duke University Press.

Collins, F.L., Simon-Kumar, R. and Friesen, W. (2020). Intersections of Inequality, Migration and Diversification. London: Palgrave Pivot, Cham.

Cox, J., (2010). An Introduction to the Phenomenology of Religion. London: A\&C Black.

Diehl, C., Koenig, M., and Ruckdeschel, K.(2009). Religiosity and gender equality: comparing natives and Muslim migrants in Germany. Ethnic and Racial Studies, 32(2), 278-301. https://doi.org/10.1080/01419870802298454

Fan, C. C. (2007). China on the Move: Migration, the State, and the Household. London: Routledge.

Fan, C. C., Sun, M., and Zheng, S. (2011). Migration and split households: A comparison of sole, couple, and family migrants in Beijing, China. Environment and Planning A, 43(9), 21642185. https://doi.org/10.1068/a44128 
Gao, Q. (2020). Reconstituting the neoliberal subjectivity of migrants: Christian theo-ethics and migrant workers in Shenzhen, China. Journal of Ethnic and Migration Studies. https://doi.org/10.1080/1369183X.2020.1739374

Gao, Q. , Qian, J. , \& Yuan, Z. . (2018). Multi-scaled secularization or postsecular present? Christianity and migrant workers in Shenzhen, china. Cultural Geographies, 25(4), 553-570. http://doi.org/10.1177/1474474018762814

Gao, Q., \& Qian, J. (2020). Migrant Workers in an Era of Religious Revival: Industrial Capitalism, Labour and Christianity in Shenzhen. The China Quarterly, 241, 62-86. http://doi.org/10.1017/S0305741019000766

Cloke, P., \& Beaumont, J. (2013). Geographies of postsecular rapprochement in the city. Progress in Human Geography, 37(1), 27-51. http://doi.org/10.1177/0309132512440208

Gökarıksel, B. (2017). The body politics of Trump's "Muslim Ban". Journal of Middle East Women's Studies, 13(3), 469-471. https://doi.org/10.1215/15525864-4179133

Hancock, A.M. (2016). Intersectionality: An intellectual history. Oxford, UK: Oxford University Press.

Hopkins, P. (2006). Youthful Muslim masculinities: gender and generational relations. Transactions of the Institute of British Geographers, 31(3), 337-352. http://doi.org/10.1111/j.1475-5661.2006.00206.x

Hopkins, P. (2018). Feminist geographies and intersectionality, Gender, Place \& Culture, 25:4, 585-590. http://doi.org/10.1080/0966369X.2018.1460331

Hopkins, P. (2019). Social geography I: intersectionality. Progress in Human Geography, 43(5), 937-947. https://doi.org/10.1177/0309132517743677

Huang, J. (2014). Being Christians in urbanizing China: the epistemological tensions of the rural churches in the city. Current Anthropology, 55(S10), S238-S247. https://doi.org/10.1086/677882

Koesel, K. J. (2013). The rise of a Chinese house church: The organizational weapon. The China Quarterly, 215, 572-589. https://doi.org/10.1017/S0305741013000684 
Kong, L. , and O. Woods . 2019. Disjunctures of belonging and belief: Christian migrants and the bordering of identity in Singapore." Population, Space and Place 25(6): 1-10. http://doi.org/10.1002/psp.2235

Kofman, E. (2004). Family-related migration: a critical review of European Studies. Journal of Ethnic and Migration Studies, 30(2),243-262.

https://doi.org/10.1080/1369183042000200687

Ley, D. (2008). The immigrant church as an urban service hub. Urban Studies, 45(10), $2057-$ 2074. https://doi.org/10.1177/0042098008094873

Long, K. (2015). The huddled masses: Immigration and inequality. London: Createspace.

Martin, P.L. (2013). The global challenge of managing migration. Washington, DC: Population Reference Bureau.

McCall, L. (2005). The complexity of intersectionality. Signs: Journal of women in culture and society, 30(3), 1771-1800. https://doi.org/10.1086/426800

Ong, A. (2007). Neoliberalism as a Mobile Technology. Transactions of the Institute of British Geographers, 32 (1), 3-8. http://doi.org/10.2307/4639996

Qian, J. \& He, S. (2012). Rethinking social power and the right to the city amidst China's emerging urbanism. Environment and Planning A, 44(12), 2801-2816.

https://doi.org/10.1068/a44373

Pew Research Center. (2011). Global Christianity: A Report on the Size and Distribution of the World's Christian Population, 19 December.

Pitre, N. Y., \& Kushner, K. E. (2015). Theoretical triangulation as an extension of feminist intersectionality in qualitative family research. Journal of Family Theory \& Review, 7(3), 284-298. https://doi.org/10.1111/jftr.12084

Pratt, G., \& Yeoh, B. (2003). Transnational (counter) topographies. Gender, place and culture: A journal of feminist geography, 10(2), 159-166.

https://doi.org/10.1080/0966369032000079541 
Pun, N. (1999). Becoming dagongmei (working girls): the politics of identity and difference in reform China. The China Journal, 42, 1-18. https://doi.org/10.2307/2667638

Pun, N. (2005). Made in China: Women factory workers in a global workplace. Durham, US: Duke University Press.

Pun, N., and Smith C. (2007). Putting transnational labour process in its place: the dormitory labour regime in post-socialist China. Work, Employment and Society, 21(1), 27-45.

https://doi.org/10.1177/0950017007073611

Rozental, A. \& Malmquist A. (2015). Vulnerability and acceptance: lesbian women's familymaking through assisted reproduction in Swedish public health care. Journal of GLBT Family Studies, 11(2): 127-150. https://doi.org/10.1080/1550428X.2014.891088

Rodó-de-Zárate, M \& Baylina, M. (2018). Intersectionality in feminist geographies, Gender, Place \& Culture, 25:4, 547-553. http://.doi.org/10.1080/0966369X.2018.1453489

Silvey, R. (2004). Power, difference and mobility: feminist advances in migration studies. Progress in Human Geography, 28(4), 490-506. https://doi.org/10.1191/0309132504ph490oa

Silvey, R. (2013). Political moves: Cultural geographies of migration and difference. In Nuala J, Schein R, Winders J.(eds). The wiley-blackwell companion to cultural geography, 409-422.

Verloo, M. (2006). Multiple inequalities, intersectionality and the European Union. European Journal of Women's Studies, 13(3), 211-228. https://doi.org/10.1177/1350506806065753

Yang, F. (2011). Religion in China: Survival and Revival under Communist Rule. Oxford: Oxford University Press

Yuval-Davis, N. (2015). Situated intersectionality and social inequality. Raisons politiques, 2, 91-100. http://doi.org/10.3917/rai.058.0091

Zhang, L. (2001). Strangers in the city: Reconfigurations of space, power, and social networks within China's floating population. Palo Alto: Stanford University Press. 
